\title{
COMPARISON OF SOME WOOD PROPERTIES OF JUVENILE BLACK PINES OF DIFFERENT ORIGIN PLANTED IN THE SAME HABITAT
}

\author{
Mustafa Burak Arslan ${ }^{1, \star}$ \\ https://orcid.org/0000-0002-3914-5763 \\ Erkan $A v c \imath^{2}$ \\ https://orcid.org/0000-0002-1475-4028 \\ Ayhan Tozluoğlu \\ https://orcid.org/0000-0002-1828-9450 \\ Turgay Birtürk \\ https://orcid.org/0000-0001-7940-0418 \\ Akın Saraçbaşı ${ }^{4}$ \\ https://orcid.org/0000-0002-8599-6825 \\ Erdal Örtel ${ }^{1}$ \\ https://orcid.org/0000-0002-0580-7423
}

\begin{abstract}
Black pine (Pinus nigra) is a significant raw material source for the forest products industry in Turkey. The purpose of this research was to study some chemical, anatomical, physical, and mechanical properties of wood obtained from juvenile black pines planted in Kavaklıdere - Muğla, originating from five different locations: Muğla, Balıkesir, Denizli, Bursa, and Kütahya. Although pines originating from Muğla and Balıkesir were good in terms of wood properties, those from Denizli, Bursa, and Kütahya exhibited no remarkable features. Black pine of Muğla origin was recommended for planting in Kavaklıdere and similar habitats, whereas pines of Denizli, Bursa, and Kütahya origins were not recommended. However, pine of Balıkesir origin may be an alternative to that of Muğla origin for black pine plantations at Kavaklıdere and similar sites.
\end{abstract}

Keywords: Anatomical properties, chemical properties, juvenile wood, mechanical properties, physical properties, wood properties. 


\section{INTRODUCTION}

The general geographical distribution of black pine (Pinus nigra) covers Anatolia, Crimea, south of the Carpathians, the Balkan Peninsula, and Cyprus. In Turkey, on the inner slopes of the North Anatolian Mountains, on the northern borders of Western Anatolia (especially the Taurus Mountains), and in South Anatolia it establishes pure forests, or mixed forests with Turkish red pine, Scots pine, cedar, juniper, fir, beech, and oak taxa (Yaltırlk and Efe 1994). According to the latest official statistics of the Republic of Turkey General Directorate of Forestry, about $19 \%$ of the 22740297 hectares of forest areas in Turkey consist of black pine. Additionally, after Turkish red pine (Pinus brutia Ten.), it is the coniferous species with the second highest distribution in Turkey (Republic of Turkey General Directorate of Forestry 2019). It is also the most frequently planted species in Turkey after Turkish red pine (Acar et al. 2011). Black pine is of great importance for forestry and the forest products industry in Turkey due to its wide distribution area and good wood properties.

The population growth and technological developments emerging since the second half of the twentieth century have led to the establishment and expanding development of the forest products industry, resulting in the increased demand for wood raw material. Because large-diameter old trees in natural forests are not enough to meet the raw material needs, juvenile wood, made available in a short time by plantation forestry, has gained in importance. During the first years of the growth period of the trees (approximately $5-20$ years), the texture of the wood extending from the pith to the exterior is defined as juvenile wood, whereas the part formed after the transition period is called mature wood (Arslan and Aydemir 2009). Juvenile wood differs from mature wood anatomically (Bao et al. 2001, Oluwafemi 2007), chemically (Bao et al. 2001, Yeh et al. 2006), and in terms of physical and mechanical properties (Bao et al. 2001, Passialis and Kiriazakos 2004, Pikk and Kasr 2006).

One of the most important differences between juvenile wood and mature wood is the higher angle of the cellulose microfibrils in the secondary wall S2 layer with the longitudinal axis of the cell (Lichtenegger et al. 1999, Deresse et al. 2003, Alteyrac et al. 2006). Microfibril angle plays a significant role in determining the mechanical properties of wood (Reiterer et al. 1999).

In coniferous trees, compared to mature wood, juvenile wood has higher lignin and extractive contents and lower cellulose content, tracheid length, cell wall thickness, density, and mechanical strength (Kretschmann 1998, Larson et al. 2001, Pikk and Kasr 2006, Yeh et al. 2006, Oluwafemi 2007, Bal et al. 2012).

Guler et al. (2007) studied the physical and mechanical properties of juvenile black pine planted in Düzce, and other studies have investigated the wood properties of mature black pine naturally grown in Dursunbey and Elekdağ (Göker 1969), and Yenice (Erten and Sözen 1994, Gündüz 1999). In addition, a number of studies have been carried out to determine the anatomical and chemical properties of black pine mature wood (Erten and İlter 1995, Ateş 2004, Hafizoğlu and Usta 2005, Sarıusta 2007) and juvenile wood (Akgül and Tozluoğlu 2009).

Guler et al. (2007) and Akgül and Tozluoğlu (2009) determined some characteristics of juvenile black pine wood; however, their studies did not mention the origins of the juvenile black pine trees that were planted in the Düzce region. In contrast, in our study, as well as finding regional differences, the tree origins were identified and compared. Thus, the aim was to reveal the origins of trees that can be planted in Kavaklidere and similar growing environments in order to achieve superior wood properties.

Consequently, this study aimed to examine some chemical, anatomical, physical, and mechanical properties of wood from juvenile black pines of five different origins planted in Kavaklıdere - Muğla, Turkey, and to determine the best provenance in terms of wood properties.

\section{MATERIAL AND METHODS}

The wood samples of juvenile black pines (Pinus nigra Arn.) were obtained from the section numbered 242 belonging to the Sub-district Directorate of the Kavaklıdere Forest District Directorate under the Muğla Forest Regional Directorate. The pines of different origins were planted in 1993 as 0-2-year-old seedlings at a spacing distance of 2,50 m-1,25 m. No pruning or thinning was carried out in the area until the trees were cut down. The slope of the field is over $30 \%$. Table 1 displays the characteristics of the study area from where 
the samples were taken.

Table 1: Characteristics of study area (Acar et al. 2019).

\begin{tabular}{|c|c|}
\hline Location & Kavaklidere - Muğla (Turkey) \\
\hline Latitude & $37^{\circ} 22^{\prime} 38.6^{\prime \prime}$ North \\
\hline Longitude & $28^{\circ} 21^{\prime} 50.4^{\prime \prime}$ East \\
\hline Altitude & $1230 \mathrm{~m}$ \\
\hline Mean temperature* & $15,42^{\circ} \mathrm{C}$ \\
\hline Average precipitation* & $1165,20 \mathrm{~mm}$ \\
\hline Soil type & loam / clay loam \\
\hline Bedrock & limestone / phyllite \\
\hline
\end{tabular}

* Average value between 1993 and 2017.

For this study, pines of five origins were selected from among those of nineteen origins. These included those originating from Balıkesir, Bursa, Denizli, Kütahya, and Muğla (Figure 1), which were chosen as representative of different parts of the Aegean Region and considering criteria such as the tree trunk flatness and diameter dimensions. A total of thirty juvenile black pines, consisting of six trees of each origin, were felled on 08 December 2016 in compliance with TSE 4176 (1984). All felled trees were twenty-five years old. When selecting the trees, we made sure that they were normal and healthy in terms of trunk and crown formation, displayed natural wood color, had fibers parallel to each other that did not show curling, and finally, that they were not suffering from insect or fungal damage. Care was taken to ensure that the trees were representative of the region. Table 2 gives information about the origins of the juvenile black pines.

Table 2: Origin information of Black pine trees.

\begin{tabular}{|c|c|c|c|c|c|c|c|}
\hline $\begin{array}{c}\text { SS* } \\
\text { National } \\
\text { Code }\end{array}$ & $\begin{array}{c}\text { Origin } \\
\text { Name }\end{array}$ & $\begin{array}{c}\text { Average } \\
\text { diameter } \\
(\mathrm{cm})\end{array}$ & $\begin{array}{c}\text { Regional } \\
\text { Directorate }\end{array}$ & $\begin{array}{c}\text { District } \\
\text { Directorate }\end{array}$ & Series & $\begin{array}{c}\text { Latitude/ } \\
\text { Longitude }\end{array}$ & $\begin{array}{c}\text { Altitude } \\
(\mathrm{m})\end{array}$ \\
\hline 70 & Balıkesir & 16,15 & Balıkesir & Alaçam & Değirmeneğrek & $\begin{array}{c}39^{\circ} 24^{\prime} 40^{\prime \prime} \\
/ \\
28^{\circ} 33^{\prime} 15^{\prime \prime}\end{array}$ & 1500 \\
\hline 83 & Bursa & 14,50 & Bursa & Mustafa Kemal Paşa & Burhandağ1 & $\begin{array}{c}39^{\circ} 54^{\prime} 10^{\prime \prime} \\
/ \\
28^{\circ} 43^{\prime} 00^{\prime \prime}\end{array}$ & 1000 \\
\hline 91 & Denizli & 14,90 & Denizli & Denizli & Merkez & $\begin{array}{c}37^{\circ} 40^{\prime} 50^{\prime \prime} \\
/ \\
29^{\circ} 04^{\prime} 20^{\prime \prime}\end{array}$ & 1250 \\
\hline 94 & Kütahya & 13,60 & Kütahya & Domaniç & Dereçarşamba & $\begin{array}{c}39^{\circ} 51^{\prime} 30^{\prime \prime} \\
/\end{array}$ & 1400 \\
$29^{\circ} 29^{\prime} 00^{\prime \prime}$ & 1000 \\
\hline 369 & Muğla & 15,50 & Muğla & Yllanlı & Yılanlı & $\begin{array}{c}37^{\circ} 11^{\prime} 23^{\prime \prime} \\
/ \\
28^{\circ} 31^{\prime} 53^{\prime \prime}\end{array}$ & 1100 \\
\hline
\end{tabular}

*SS: Seed Stan.

For the physical and mechanical tests, logs were taken from the tree height of 2,00 $\mathrm{m}-4,00 \mathrm{~m}$. For chemical analyses, discs were obtained from the bottom, middle, and peak points of the logs. Discs were collected at chest height (about 1,30 m) of the logs for the anatomical measurements (Figure 2).

The wood flour was obtained from the discs taken from the bottom, middle and peak sections according to TAPPI T 257 om-85 (1985), mixed homogeneously, and then mixed homogeneously for each origin separately. The main chemical components consisted of holocellulose (Wise and Karl 1962), $\alpha$-cellulose (TAPPI T 203 os-71 (1975)), lignin (TAPPI T 222 om-88 (1988)), and ash (TAPPI T 211 om-93 (1993)). Solubility properties were then determined, including for alcohol-benzene (TAPPI T $204 \mathrm{~cm}-97$ (1997)), 1\% NaOH (TAPPI T 212 om-98 (1998)), and hot and cold water (TAPPI T 207 cm-93 (1993)). 


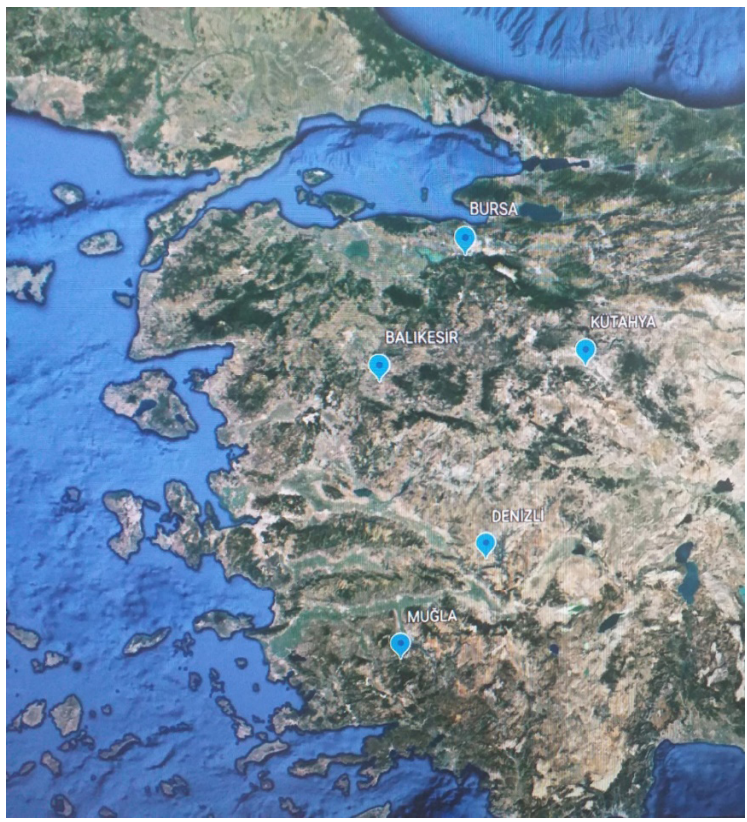

Figure 1: Map of origins of Black pine trees.

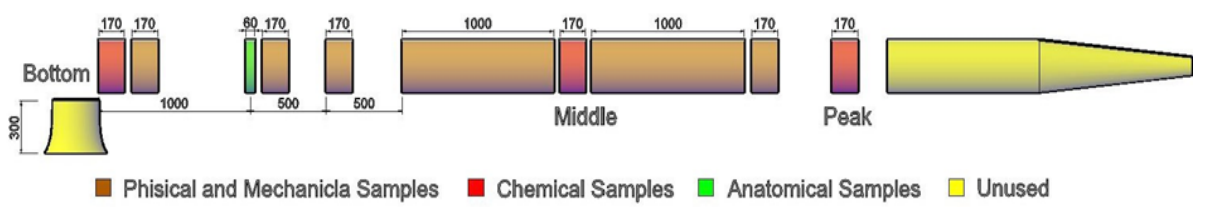

Figure 2: Scheme of sampling specimens from logs.

For anatomical measurements and amounts, the wood samples were boiled in distilled water and immersed in a solution containing equal amounts of alcohol-glycerin-distilled water. Sections taken using a sliding microtome were stained with safranin O made in continuous preparations (Gerçek 1984, Gerçek 1997, Merev 1998 referring to Merev 1998, Ives 2001). The Schultze method (potassium chlorate-nitric acid) was used for the maceration process. For the sample preparations the released wood elements were washed with distilled water, filtered, rinsed with alcohol, and stained with safranin O. Anatomical properties like tracheid length, tracheid width, tracheid cell-wall thickness, tracheid lumen width, number of tracheids per mm, ray cell height, and number of ray cells per mm were investigated.

To determine physical and mechanical properties, test samples were taken from the logs and discs according to TSE 2470 (1976). In the cutting of the test samples, care was taken that no pith or wood defects were included. Physical properties were tested, including air-dry density, oven-dry density, volume-density TSE 2472 (1976), shrinkage TSE 4083 (1983), TSE 4085 (1983), and swelling TSE 4084 (1983), TSE 4086 (1983) and mechanical properties such as bending strength TSE 2474 (1976), modulus of elasticity TSE 2478 (1976), and compression strength TSE 2595 (1977).

The data obtained from the physical and mechanical tests, chemical analyses, and anatomical measurements and amounts were subjected to one-way analysis of variance (ANOVA). The Duncan's test was then performed to determine separate groups among the origins that differed according to the arithmetic means. 


\section{RESULTS AND DISCUSSION}

The results of the arithmetic means and statistical analyses for the chemical properties of the juvenile black pine woods of different origins together with results of some previous studies on juvenile and mature black pine are displayed in Table 3. Significant differences were found in the main chemical compounds and solubility ratios of the wood samples obtained from juvenile black pines of different origins. The highest cellulose and lignin contents were in the wood of Balıkesir origin and the highest holocellulose content in that of Muğla origin. However, the lowest cellulose and lignin ratios were found in the samples of Muğla origin, and the lowest holocellulose ratio in those of Kütahya origin. Moreover, the Denizli origin samples stood out for their extractives content.

Table 3: Chemical properties of juvenile black pine of different origins.

\begin{tabular}{|c|c|c|c|c|c|c|c|c|}
\hline $\begin{array}{c}\text { Chemical } \\
\text { Properties } \\
(\%)\end{array}$ & $\begin{array}{c}\text { No. of } \\
\text { Samples }\end{array}$ & Pr & Balıesir & Bursa & Denizli & Kütahya & Muğla & JTW \\
\hline
\end{tabular}

JTW: Juvenile Tree Wood (Akgül and Tozluoğlu 2009), MTW: Mature Tree Wood (Usta 1993), \pm indicates standard deviation. Values with the same letter are statistically the same at the 0,05 significance level (Duncan's test).

The cellulose and lignin contents of samples of all provenances except for Muğla were found to be compatible with the results for juvenile black pine obtained by Akgül and Tozluoğlu (2009). However, only the Muğla samples exhibited holocellulose contents similar to their results, with the samples of other origins found to be lower. Except for the cold-water solubility, the extractive contents of the wood of different origins in this study were generally found to be close to or higher than the results reported by Akgül and Tozluoğlu (2009).

When our juvenile pines of different origins were compared with mature black pine, it was determined that holocellulose (72,3 \% - Usta 1993; 69,25\% - Erten and İlter 1995; 72,34 \% - Ateş 2004; 72,57 \% - Kılıç et al. 2010) and cellulose ratios (43,55\% - Ateş 2004; 46,80\% - Hafizoğlu and Usta 2005; 46,5 \% - Kılıç et al. $2010)$ were lower and lignin rates $(28,50 \%$ - Usta $1993 ; 26,40 \%$ - Ateș 2004; $27,90 \%$ - Hafizoğlu and Usta $2005 ; 26,74 \%$ - Kilıç et al. 2010) were higher, except for the Muğla samples. One notable finding in this study was that the lignin content of the Muğla origin sample was near to that of mature black pine. The extractive contents procured from mature black pine by Usta (1993), Ateş (2004), Hafizoğlu and Usta (2005), and Kılıç et al. (2010) were similar to or lower than those of the juvenile pine samples of different origins in this study.

Table 4 presents the arithmetic means and statistical analyses pertaining to anatomical features together with those of previous works on black pine. Except for tracheid cell wall thickness, significant differences were determined in the anatomical parameters of wood samples taken from the juvenile black pine of different origins. 
Table 4: Anatomical properties of juvenile black pine of different origins.

\begin{tabular}{|c|c|c|c|c|c|c|c|c|c|}
\hline $\begin{array}{c}\text { Anatomical } \\
\text { parameters }\end{array}$ & $\begin{array}{c}\text { No, of } \\
\text { Samples }\end{array}$ & Pr & Balıkesir & Bursa & Denizli & Kütahya & Muğla & JTW & MTW \\
\hline $\begin{array}{c}\text { Tracheid length } \\
(\mu \mathrm{m})\end{array}$ & 180 & $\mathrm{p}<0,000$ & $\begin{array}{c}2678,95 \pm \\
685,88 \mathrm{AB}\end{array}$ & $\begin{array}{c}2868,08 \pm \\
691,10 \mathrm{C}\end{array}$ & $\begin{array}{c}2568,28 \pm \\
611,40 \mathrm{~A}\end{array}$ & $\begin{array}{c}2846,26 \pm \\
621,17 \mathrm{C}\end{array}$ & $\begin{array}{c}2747,64 \pm \\
621,49 \mathrm{BC}\end{array}$ & 1120 & 3473,80 \\
\hline $\begin{array}{c}\text { Tracheid width } \\
(\mu \mathrm{m})\end{array}$ & 180 & $\mathrm{p}<0,010$ & $\begin{array}{c}40,74 \pm 9,43 \\
\mathrm{~A}\end{array}$ & $\begin{array}{c}40,64 \pm 8,40 \\
\mathrm{~A}\end{array}$ & $\begin{array}{c}42,92 \pm 8,96 \\
\mathrm{~B}\end{array}$ & $\begin{array}{c}41,46 \pm 7,98 \\
\mathrm{AB}\end{array}$ & $\begin{array}{c}43,25 \pm 9,65 \\
\mathrm{~B}\end{array}$ & 36,12 & 43,45 \\
\hline $\begin{array}{c}\text { Tracheid lumen } \\
\text { width }(\mu \mathrm{m})\end{array}$ & 180 & $\mathrm{p}<0,09$ & $\begin{array}{c}29,54 \pm 8,74 \\
\mathrm{AB}\end{array}$ & $\begin{array}{c}28,84 \pm 8,77 \\
\mathrm{~A}\end{array}$ & $\begin{array}{c}31,14 \pm 9,09 \\
\mathrm{BC}\end{array}$ & $\begin{array}{c}29,69 \pm 7,89 \\
\mathrm{AB}\end{array}$ & $\begin{array}{c}31,74 \pm 9,28 \\
\mathrm{C}\end{array}$ & 26,23 & 27,75 \\
\hline $\begin{array}{c}\text { Tracheid cell } \\
\text { wall thickness } \\
(\mu \mathrm{m})\end{array}$ & 180 & $\mathrm{p}<0,732$ & $\begin{array}{c}5,60 \pm 2,09 \\
\mathrm{~A}\end{array}$ & $\begin{array}{c}5,90 \pm 2,55 \\
\mathrm{~A}\end{array}$ & $\begin{array}{c}5,89 \pm 2,60 \\
\mathrm{~A}\end{array}$ & $\begin{array}{c}5,88 \pm 2,52 \\
\mathrm{~A}\end{array}$ & $\begin{array}{c}5,75 \pm 2,39 \\
\mathrm{~A}\end{array}$ & 4,95 & 15,20 \\
\hline $\begin{array}{c}\text { Ray cell height } \\
(\mu \mathrm{m})\end{array}$ & 180 & $\mathrm{p}<0,000$ & $\begin{array}{c}185,07 \pm \\
44,73 \mathrm{~B}\end{array}$ & $\begin{array}{c}166,48 \pm \\
37,10 \mathrm{~A}\end{array}$ & $\begin{array}{c}172,38 \pm \\
46,43 \mathrm{~A}\end{array}$ & $\begin{array}{c}167,45 \pm \\
40,42 \mathrm{~A}\end{array}$ & $\begin{array}{c}197,01 \pm \\
51,63 \mathrm{C}\end{array}$ & - & 176,10 \\
\hline $\begin{array}{c}\text { Number of } \\
\text { tracheids } / \mathrm{mm} 2\end{array}$ & 180 & $\mathrm{p}<0,048$ & $\begin{array}{c}811,67 \pm \\
89,83 \mathrm{C}\end{array}$ & $\begin{array}{c}802,12 \pm \\
96,30 \mathrm{AB}\end{array}$ & $\begin{array}{c}783,27 \pm \\
98,71 \mathrm{~A}\end{array}$ & $\begin{array}{c}787,80 \pm \\
97,75 \mathrm{~A}\end{array}$ & $\begin{array}{c}796,94 \pm \\
105,21 \mathrm{AB}\end{array}$ & - & 6156,60 \\
\hline $\begin{array}{c}\text { Number of ray } \\
\text { cells } / \mathrm{mm}\end{array}$ & 180 & $\mathrm{p}<0,061$ & $\begin{array}{c}3,73 \pm 1,32 \\
\mathrm{AB}\end{array}$ & $\begin{array}{c}3,53 \pm 0,93 \\
\mathrm{~A}\end{array}$ & $\begin{array}{c}3,85 \pm 1,06 \\
\mathrm{~B}\end{array}$ & $\begin{array}{c}3,78 \pm 1,10 \\
\mathrm{~B}\end{array}$ & $\begin{array}{c}3,81 \pm 1,16 \\
\mathrm{~B}\end{array}$ & - & 4,60 \\
\hline
\end{tabular}

JTW: Juvenile Tree Wood (Akgül and Tozluoğlu 2009), MTW: Mature Tree Wood (Sarıusta 2007), \pm indicates standard deviation. Values with the same letter are statistically the same at the 0,05 significance level (Duncan's test).

The highest tracheid length was detected in the samples of Bursa origin, the highest tracheid width, tracheid lumen width, and ray cell height in those of Muğla origin, the maximum number of tracheids per $\mathrm{mm}^{2}$ in those of Balıkesir origin, and the maximum number of ray cells per $\mathrm{mm}$ in those of Bursa origin. In contrast, the lowest tracheid length was found in samples of Balıkesir origin, the lowest tracheid width, tracheid lumen width, ray cell height, and minimum number of ray cells per mm in those of Bursa origin, and the minimum number of tracheids per $\mathrm{mm}^{2}$ in those of Denizli origin.

It was observed that the tracheid length, tracheid width, and tracheid cell wall thickness values of the juvenile black pine from the origins in this study were higher than the values found by Akgül and Tozluoğlu (2009). İstek et al. (2010) stated that the tracheid fiber properties of black pine significantly improve until the age of 90. Passialis and Kiriazakos (2004) reported that the tracheid length of juvenile wood of naturally grown fir trees was shorter compared to mature wood. The tracheid length and width of mature black pine were respectively found by Ataç (2009) as 2390 and 42,00 $\mu \mathrm{m}$ and Ateş (2004) as $2770 \mu \mathrm{m}$ and 40,60 $\mu \mathrm{m}$. These values are close or lower than those of our juvenile wood of differing origins. Other studies of mature black pine (Göker 1969, Erten and İlter 1995) found higher tracheid length and width than in our juvenile pine. The lumen widths obtained from this study, when compared with mature black pine values in the literature, were determined to be similar (30,40 $\mu \mathrm{m}$ - Ataç 2009), higher (27,32 $\mu \mathrm{m}$ - Ateş 2004; 27,75 $\mu \mathrm{m}$ - Sarıusta 2007), or lower (41,50 $\mu \mathrm{m}$ - Erten and İlter 1995). Juvenile wood in our study showed values lower than the ray cell height $(176,10$ $\mu \mathrm{m})$ and number of ray cells per mm (4,60) reported by Saruusta (2007) for mature black pine. Göker (1969) determined 998 and 1030 tracheids per $\mathrm{mm}^{2}$ for mature black pines grown in Dursunbey and Elekdağ, respectively. Gündüz (1999) published the number of tracheids per $\mathrm{mm}^{2}$ as 1187 in Yenice mature black pine. These results were higher than the number of tracheids per $\mathrm{mm}^{2}$ of the juvenile black pine in this study.

The arithmetic means and statistical analyses for the physical properties are displayed in Table 5. Other than for tangential shrinkage, longitudinal shrinkage, and longitudinal swelling, significant differences were detected in the physical properties of wood samples obtained from the juvenile black pine of different origins. 
Table 5: Physical properties of juvenile black pine of different origins.

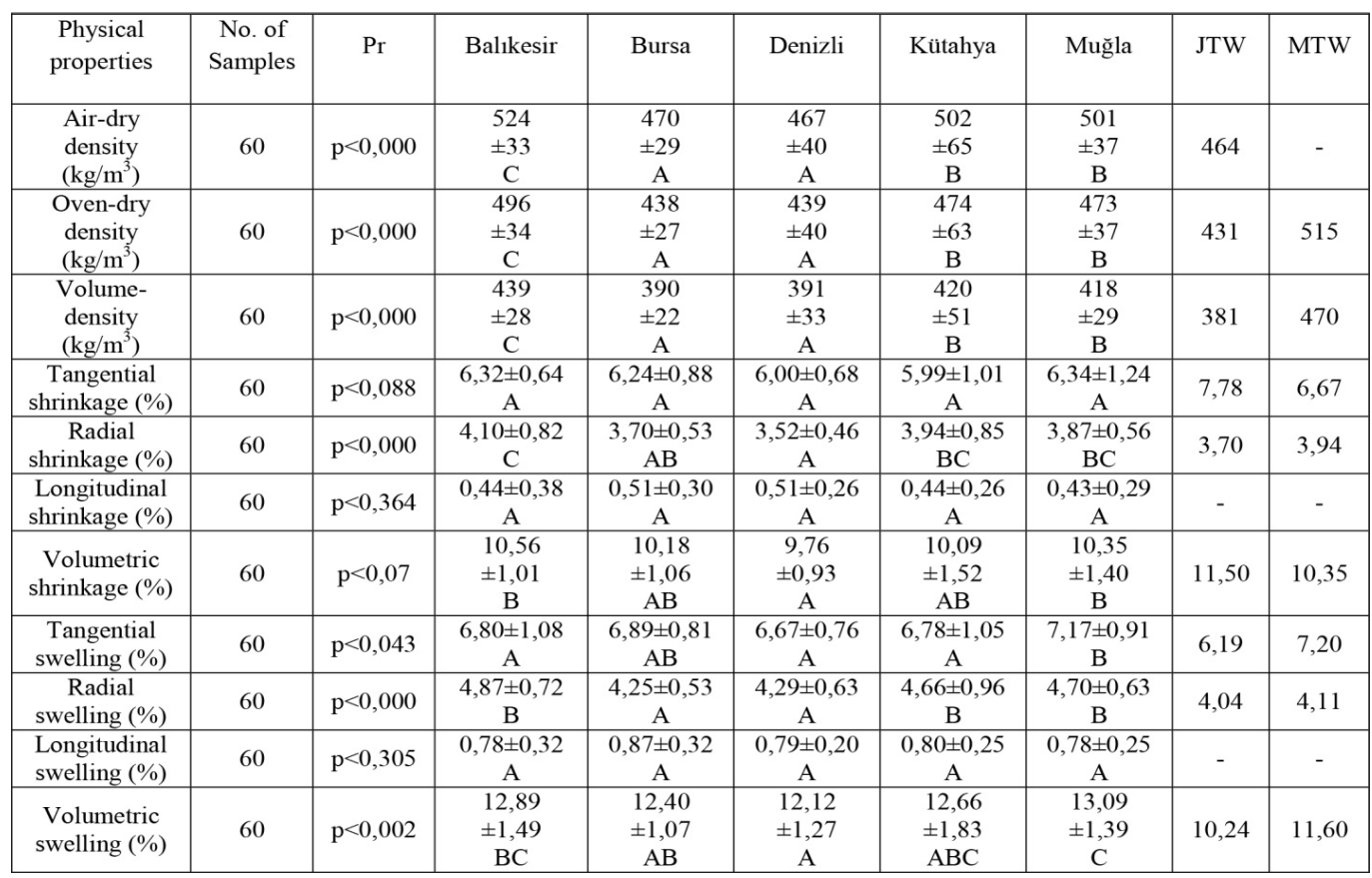

JTW: Juvenile Tree Wood (Guler et al. 2007), MTW: Mature Tree Wood (Erten and Sözen 1994), \pm indicates standard deviation. Values with the same letter are statistically the same at the 0,05 significance level (Duncan's test).

The highest air-dry density, oven-dry density, volumetric density, radial shrinkage, volumetric shrinkage, and radial swelling were found in samples of Balıkesir origin and the highest tangential swelling and volumetric swelling were in those of Muğla origin, whereas the lowest air-dry density, radial shrinkage, volumetric shrinkage, tangential swelling, and volumetric swelling were in samples of Denizli origin and the lowest oven-dry density, volumetric-density, and radial swelling appeared in those of Bursa origin.

The density (air-dry and oven-dry) and volume density values reported by Guler et al. (2007) in juvenile black pine were lower than in the samples of Balıkesir, Muğla, and Kütahya origins, and close to those of Denizli and Bursa origins. In addition, the wood-water relation of the juvenile wood in this study indicated lower volumetric shrinkage and higher volumetric swelling compared to the values published by Guler et al. (2007) in juvenile black pine. Bal et al. (2012) stated that the density of juvenile Taurus cedar wood was lower than that of mature wood. Additional, Bao et al. (2001) reported that, except for loblolly pine and slash pine, the density of other mature woods of 10 tree species that grow naturally and in plantations was higher than in juvenile wood. Göker (1969) determined the densities of mature black pine (air-dry and oven-dry) grown in Dursunbey and Elekdağ as $560 \mathrm{~kg} / \mathrm{m}^{3}$ and $520 \mathrm{~kg} / \mathrm{m}^{3}$ and $550 \mathrm{~kg} / \mathrm{m}^{3}$ and $517 \mathrm{~kg} / \mathrm{m}^{3}$, respectively. Gündüz (1999) found the air-dry and oven-dry densities of the mature black pine in Yenice as $590 \mathrm{~kg} / \mathrm{m}^{3}$ and $540 \mathrm{~kg} /$ $\mathrm{m}^{3}$. The densities of the juvenile wood samples in our study were distinctively lower than the values of Göker (1969) and Gündüz (1999). Although the shrinkages of our juvenile samples were lower than in the mature black pine in Dursunbey and Elekdağ (13,19 \% and 12,50 \% - Göker 1969), they were close to the values of mature black pine in some studies (10,35 \% - Erten and Sözen 1994; 10,56 \% - Gündüz 1999; 9,93 \% - Döğdü 2006). Moreover, when comparing the swelling percentages, our juvenile samples demonstrated higher values than those of mature black pine (11,60 \% - Erten and Sözen 1994; 11,31 \% - Gündüz 1999; 10,42 \% - Döğdü 2006).

It can be said that the densities of juvenile black pine of different origins were compatible with those found in the literature, although their swelling properties were not (Bao et al. 2001, Pikk and Kasr 2006, Bal et al. 2012). It was expected that the wood originating from Balıkesir, with the highest number of tracheids per $\mathrm{mm}^{2}$, would also have the highest density. 
The arithmetic means and statistical analyses of the mechanical properties are presented in Table 6 . Significant differences were determined in the mechanical properties of wood samples taken from the juvenile black pine of different origins.

Table 6: Mechanical properties of juvenile black pine of different origins.

\begin{tabular}{|c|c|c|c|c|c|c|c|c|c|}
\hline $\begin{array}{c}\text { Mechanical } \\
\text { properties }\end{array}$ & $\begin{array}{c}\text { No. of } \\
\text { Samples }\end{array}$ & Pr & Balıkesir & Bursa & Denizli & Kütahya & Muğla & JTW & MTW \\
\hline $\begin{array}{c}\text { Bending } \\
\text { strength } \\
\text { (MPa) }\end{array}$ & 36 & $\mathrm{p}<0,000$ & $\begin{array}{c}74,59 \pm 9,54 \\
\mathrm{BC}\end{array}$ & $\begin{array}{c}71,11 \pm 9,21 \\
\mathrm{~B}\end{array}$ & $\begin{array}{c}66,12 \pm 8,12 \\
\mathrm{~A}\end{array}$ & $\begin{array}{c}72,57 \pm 14,75 \\
\mathrm{~B}\end{array}$ & $\begin{array}{c}78,01 \pm 9,89 \\
\mathrm{C}\end{array}$ & 79,01 & 119,91 \\
\hline $\begin{array}{c}\text { Modulus of } \\
\text { elasticity } \\
(\mathrm{MPa})\end{array}$ & 36 & $\mathrm{p}<0,000$ & $\begin{array}{c}6756,07 \pm \\
1559,50 \\
\mathrm{~B}\end{array}$ & $\begin{array}{c}6543,04 \pm \\
1097,26 \\
\mathrm{~B}\end{array}$ & $\begin{array}{c}5666,02 \pm \\
1290,83 \\
\mathrm{~A}\end{array}$ & $\begin{array}{c}66664,04 \pm \\
1730,85 \\
\mathrm{~B}\end{array}$ & $\begin{array}{c}7571,68 \pm \\
1430,39 \\
\mathrm{C}\end{array}$ & - & 7061,75 \\
\hline $\begin{array}{c}\text { Compression } \\
\text { strenth } \\
(\mathrm{MPa})\end{array}$ & 36 & $\mathrm{p}<0,000$ & $\begin{array}{c}47,79 \pm 8,31 \\
\mathrm{C}\end{array}$ & $\begin{array}{c}43,57 \pm 4,89 \\
\mathrm{~B}\end{array}$ & $\begin{array}{c}36,38 \pm 5,24 \\
\mathrm{~A}\end{array}$ & $\begin{array}{c}45,49 \pm 8,71 \\
\mathrm{BC}\end{array}$ & $\begin{array}{c}45,01 \pm 6,74 \\
\mathrm{BC}\end{array}$ & 42,4 & 56,93 \\
\hline
\end{tabular}

JTW: Juvenile Tree Wood (Guler et al. 2007), MTW: Mature Tree Wood (Gündüz 1999), \pm indicates standard deviation. Values with the same letter are statistically the same at the 0,05 significance level (Duncan's test).

The highest bending strength and elasticity module were seen in the samples of Muğla origin and the highest-pressure strength in those of Balıkesir origin, whereas the poorest mechanical properties were found in those of Denizli origin.

It was revealed that the bending strength of juvenile black pine reported by Guler et al. (2007) was similar to that of the wood of Muğla origin, but higher than the bending strength found for samples of the other origins. The compression strength was higher than in the wood of Denizli origin, close to the wood of Bursa origin, and lower than found in samples of the other origins.

Gündüz (1999) reported the bending strength of mature black pine grown in Yenice as $119,90 \mathrm{MPa}$ and Göker (1969) reported bending strength in mature black pine in Dursunbey and Elekdağ as 107,50 MPa and $92,87 \mathrm{MPa}$, respectively. The bending strength reached in both studies was much higher than seen in our juvenile pine samples. However, the bending strength of mature black pine $(61,85 \mathrm{MPa})$ found by Erten and Sözen (1994) was lower than in the juvenile black pine in this study. The elasticity module values (8995 MPa - 13242,30 MPa) determined in black pine wood samples taken from different altitudes and bedrocks in the Alaçam mountains by Sevgi et al. (2010) were higher than the values found in the juvenile black pine in our work.

The compression strength of the samples of Balıkesir, Kütahya, and Muğla origins were higher than in Göker>s (1969) Dursunbey mature black pine (43,74 MPa) and close to that of Elekdağ mature black pine (46,97 MPa). In addition, the compression strength determined in Yenice mature black pine $(56,93 \mathrm{MPa})$ by Gündüz (1999) was higher than found in the juvenile black pine in our study.

In general, juvenile wood has lower mechanical properties than mature wood (Bao et al. 2001, Passialis and Kiriazakos 2004, Pikk and Kasr 2006, Bal et al. 2012). Our results were similar to those in the literature.

\section{CONCLUSIONS}

The trees originating in Muğla and Balıkesir were superior in terms of wood properties, whereas no prominent features were exhibited by the trees of Bursa and Kütahya origins and those of Denizli origin yielded the lowest density and strength values.

Juvenile wood is not sufficient for the log and timber industry because its diameter and strength properties are lower than in mature wood. However, it is suitable for other industries where wood raw material is used. When the chemical, anatomical, physical, and mechanical wood properties of our juvenile black pine were considered in terms of their origins, all of them were found to be suitable for use in pulp and paper 
production and composite-board manufacturing. However, wood of Muğla origin was found to be best for pulp and paper production and that of Balıkesir origin for composite board manufacturing. Furthermore, only Muğla and Balıkesir origins were seen as the best sources for small-diameter poles suitable for usage as mine poles, telephone poles, and such.

Considering wood properties and areas of usage, the pines originating in the Muğla region were recommended for black pine plantations in Kavaklidere and similar habitats. However, because of their good wood properties, it was understood that those of Balıkesir origin might be an alternative to the Muğla origin pines. Thus, the pines of Balıkesir origin were the second choice after those of Muğla origin for industrial black pine plantations. The proximity of Muğla to Kavaklıdere and the genetic characteristics of the pines originating in Balikesir may have enabled the trees of these two provenances to exhibit better wood characteristics. On the other hand, the wood properties of the Bursa and Kütahya pines indicated no priority usage areas and the wood properties of the Denizli pine were prominently lower than for the wood of the other origins. Thus, black pines of Denizli, Bursa, and Kütahya origins were not recommended for industrial planting in Kavaklidere or similar environments.

\section{ACKNOWLEDGEMENTS}

This study was supported by the Republic of Turkey General Directorate of Forestry with the project number 15.7101. The authors would like to thank the team of the project entitled "Provenance trials of Turkish black pine (Pinus nigra Arn. subsp. nigra var. caramanica) in Ege Region" and the staff of Kavaklidere Forest District Directorate for the black pine seedling planting and maintenance. The authors would also like to thank Bilal Altun, the Forest Sub-district Director, for his contribution in the felling, barking, and transporting of trees to the laboratory.

\section{REFERENCES}

Acar, F.C.; Altun, Z.G.; Boza, A. 2011. Provenance trials of Turkish black pine (Pinus nigra Arn. subsp. nigra var. caramanica) in Ege Region: Fifteenth year results. Technical Bulletin No: 50. Ege Forestry Research Institute: İzmir, Turkey. (in Turkish)

Acar, F.C.; Altun, Z.G.; Boza, A.; Örtel, E. 2019. Provenance trials of Turkish black pine (Pinus nigra Arn. subsp. nigra var. caramanica) in Ege Region: Twentieth- and twenty-fifth-year result. Project Interim Report 15.1704. Ege Forestry Research Institute: İzmir, Turkey. (in Turkish, unpublished)

Akgül, M.; Tozluoglu, A. 2009. Some chemical and morphological properties of juvenile woods from beech (Fagus orientalis L.) and pine (Pinus nigra A.) plantations. Trends Appl Sci Res 4(2): 1-10. https://doi.org/10.3923/tasr.2009.116.125

Alteyrac, J.; Cloutier, A.; Zhang, S.Y. 2006. Characterization of juvenile wood to mature wood transition age in black spruce (Picea mariana (Mill.) B.S.P.) at different stand densities and sampling heights. Wood Sci Technol 40(2): 124-138. https://doi.org/10.1007/s00226-005-0047-4

Arslan, M.B.; Aydemir, D. 2009. Juvenile wood and its properties. Journal of Bartin Faculty of Forestry 11(16): 25-32. (in Turkish). https://dergipark.org.tr/tr/pub/barofd/issue/3398/46801

Ataç, Y. 2009. Examination of some softwood and hardwood trees in terms of paper properties of their sapwood and heartwood. Ph.D. Thesis, Bartın University, Bartın, Turkey (in Turkish).

Ateş, S. 2004. Comparative regression models on experimental designing the kraft pulping conditions of Anatolian black pine (Pinus nigra Subsp. pallasiana) wood. Ph.D. Thesis, Karadeniz Technical University, Trabzon, Turkey (in Turkish).

Bal, B.C.; Bektaş, İ.; Kaymakçı, A. 2012. Some physical and mechanical properties of juvenile wood and mature wood of Taurus cedar. KSU J Eng Sci 15(2): 17-27. (in Turkish). http://jes.ksu.edu.tr/en/pub/ issue $/ 19361 / 205324$

Bao, F.C.; Jiang, Z.H.; Jiang, X.M.; Lu, X.X.; Luo, X.Q.; Zhang, S.Y. 2001. Different in wood properties between juvenile wood and mature wood in 10 species grown in China. Wood Sci Technol 35(4): 363-375. http://dx.doi.org/10.1007/s002260100099 
Deresse, T.; Shepard, R.K.; Shaler, S.M. 2003. Microfibril angle variation in red pine (Pinus resinosa Ait.) and its relation to the strength and stiffness of early juvenile wood. Forest Prod J 53(7): 34-40. https://www.proquest.com/docview/214638606/fulltextPDF/3460B7D09D6D4110PQ/1?accountid=17248

Döğdü, Y.C. 2006. Some technological properties of (Pinus nigra Arn. subsp. pallasiana var. pallasiana) and determining the kiln drying schedules. M.Sc. Thesis, Zonguldak Karaelmas University, Bartın, Turkey. (in Turkish).

Erten, A.P.; İlter, E. 1995. Studies on the determination of chemical components of Austrian pine (Pinus nigra Arnold.) wood. Turkish Forestry Research Institute, Technical Bulletin No: 250. Ankara, Turkey. (in Turkish).

Erten, P.; Sözen, R. 1994. Studies on the determination of some physical and mechanical properties of Pinus pinea, Pinus nigra Arnold and Acer platanoides wood. Central Anatolia Forestry Research institute, Technical Bulletin No: 266. Ankara, Turkey. (in Turkish).

Gerçek, Z. 1984. The interior morphological characteristics of (Camellia sinensis (L.) Kuntze) grown in Turkey and the effect of different growing conditions upon these characteristics. Ph.D. Thesis, Karadeniz University, Trabzon, Turkey. (in Turkish).

Gerçek, Z. 1997. Doğu karadeniz bölgesindeki egzotik angiospermae (Kapalı tohumlular) taksonlarının odun atlası. Karadeniz Teknik Üniversitesi Basımevi: Trabzon, Turkey. (in Turkish).

Göker, Y. 1969. A study of some physical and mechanical properties and use possibilities of (Pinus nigra Arnl. var. pallasiana) from Elekdağ and Dursunbey. Journal of the Faculty of Forestry Istanbul University 19(2): 91-135. (in Turkish).

Guler, C.; Çopur, Y.; Akgul, M.; Buyuksari, Ü. 2007. Some chemical, physical and mechanical properties of juvenile wood from black pine (Pinus nigra Arnold) plantations. J Appl Sci 7(5): 755-758. https://doi.org/10.3923/jas.2007.755.758

Gündüz, G. 1999. Anatomic, technological and chemical properties of Camiyanı Black Pine (Pinus nigra Arn. subsp. pallasiana var. pallasiana). Ph.D. Thesis, Zonguldak Karaelmas University, Bartın, Turkey. (in Turkish).

Hafızoğlu, H.; Usta, M. 2005. Chemical composition of coniferous wood species occurring in Turkey. Holz Roh Werkst 63(1): 83-85. https://doi.org/10.1007/s00107-004-0539-1

İstek, A.; Gülsoy, S.K.; Eroğlu, H. 2010. The comparison of fiber properties of sapwood and heartwood of black pine. In Proceedings of Third National Black Sea Forestry Congress, May 20-22. Artvin Çoruh University, Faculty of Forestry, Artvin, Turkey, pp: 1916-1924. (in Turkish).

Ives, E. 2001. A guide to wood microtomy: making quality microslides of wood sections. Ipswich, United Kingdom.

Kılıç, A.; Sarıusta, S.E.; Hafızoğlu, H. 2010. Chemical Structure of Compression Wood of Pinus sylvestris, P. nigra and P. brutia. Journal of Bartin Faculty of Forestry 12(18): 33-39. (in Turkish). https://dergipark. org.tr/tr/pub/barofd/issue/3396/46779

Kretschmann, D.E. 1998. Properties of juvenile wood. techline, properties and use of wood, composites, and fiber products. United States Department of Agriculture, Forest Service, Forest Products Laboratory: Washington, DC, USA. https://www.fpl.fs.fed.us/documnts/techline/properties-of-juvenile-wood.pdf

Larson, P.R.; Kretschmann, D.E.; Clark, A.I.; Isebrands, J.G. 2001. Formation and properties of juvenile wood in Southern pines: A synopsis. Gen. Tech. Rep. FPL-GTR-129. U.S. Department of Agriculture Forest Service, Forest Products Laboratory: Madison, WI, USA. https://doi.org/10.2737/FPL-GTR-129

Lichtenegger, H.; Reiterer, A.; Stanzl-Tschegg, S.E.; Fratzl, P. 1999. Variation of cellulose microfibril angles in softwoods and hardwoods-a possible strategy of mechanical optimization. J Struct Biol 128(3): 257269. https://doi.org/10.1006/jsbi.1999.4194 
Merev, N. 1998. Doğu karadeniz bölgesindeki doğal angiospermae taksonlarının odun anatomisi. Karadeniz Teknik Üniversitesi Basımevi: Trabzon, Türkiye (in Turkish).

Oluwafemi, O.A. 2007. Wood properties and selection for rotation length in Caribbean pine (Pinus caribaea Morelet) grown in Afaka, Nigeria. American-Eurasian J Agric Environ Sci 2(4): 359-363. https://www.idosi.org/aejaes/aejaes2(4).htm

Passialis, C.; Kiriazakos, A. 2004. Juvenile and mature wood of naturally-grown fir trees. Holz Roh Werkst 62(6): 476-478. https://doi.org/10.1007/s00107-004-0525-7

Pikk, J.; Kask, R. 2006. Mechanical properties of juvenile wood of Scots pine (Pinus sylvestris L.) on Myrtillus forest site type. Balt For 10(1): 72-78. https://www.balticforestry.mi.lt/bf/index.php?option=com content\&view $=$ article \&catid $=14 \& \mathrm{id}=224$

Reiterer, A.; Lichtenegger, H.; Tschegg, S.; Fratzl P. 1999. Experimental evidence for a mechanical function of the cellulose microfibril angle in wood cell walls. Philos Mag A 79(9): 2173-2184. https://doi.org/10.1080/01418619908210415

Republic of Turkey General Directorate of Forestry. 2019. Forestry statistics. (in Turkish). https://www.ogm.gov.tr/Sayfalar/PageNotFoundError.aspx?requestUrl=https://www.ogm.gov.tr/ekutuphane/ Sayfalar/Istatistikler.aspx

Sarıusta, S.E. 2007. Investigations on anatomical and chemical properties of reaction wood of Pinus sylvestris (L.), Pinus nigra (Arnold.) and Pinus brutia (Ten.). M.Sc. Thesis, Zonguldak Karaelmas University, Bartın, Turkey (in Turkish).

Sevgi, O.; Y1lmaz, Y.; Carus, S.; Dündar, T.; Kavgacı, A.; Tecimen, H.B. 2010. Growth - nutrition models and wood technology of black pine forests in relation with altitude at Alaçam Mountains. Turkish Scientific and Technical Research Council Project Last Report, 1040551. Ankara, Turkey (in Turkish). https://app.trdizin.gov.tr/publication/project/detail/TVRBMU1URXg=

TAPPI. 1975. TAPPI T 203 os-71: Alpha, beta and gamma cellulose in pulp. TAPPI Press: Atlanta, Ga, USA.

TAPPI. 1985. TAPPI T $257 \mathrm{~cm}-85$ : Sampling and preparing wood for analysis. TAPPI Press: Atlanta, Ga, USA.

TAPPI. 1988. TAPPI T 222 om-88: Acid-insoluble lignin in wood and pulp. TAPPI Press: Atlanta, Ga, USA.

TAPPI. 1993. TAPPI T $207 \mathrm{~cm}-93$ : Water solubility of wood and pulp. TAPPI Press: Atlanta, Ga, USA.

TAPPI. 1993. TAPPI T 211 om-93: Ash in wood and pulp. TAPPI Press: Atlanta, Ga, USA.

TAPPI. 1997. TAPPI T $204 \mathrm{~cm}-97$ : Solvent extractives of wood and pulp. TAPPI Press: Atlanta, Ga, USA.

TAPPI. 1998. TAPPI T 212 om-98: One percent sodium hydroxide solubility of wood and pulp. TAPPI Press: Atlanta, Ga, USA.

TSE. 1976. TS 2470: Wood - sampling methods and general requirements for physical and mechanical tests. TSE: Ankara, Turkey (in Turkish).

TSE. 1976. TS 2472: Wood - determination of density for physical and mechanical tests. TSE: Ankara, Turkey (in Turkish).

TSE. 1976. TS 2474: Wood - determination of ultimate strength in static bending. TSE: Ankara, Turkey (in Turkish).

TSE. 1976. TS 2478: Wood - determination of modulus of elasticity in static bending. TSE: Ankara, Turkey (in Turkish). 
TSE. 1977. TS 2595: Wood - determination of ultimate stress in compression parallel to grain. TSE: Ankara, Turkey (in Turkish).

TSE. 1983. TS 4083: Wood - determination of radial and tangential shrinkage. TSE: Ankara, Turkey (in Turkish).

TSE. 1983. TS 4084: Wood - determination of radial and tangential swelling. Turkish Standarts Institution: Ankara, Turkey (in Turkish).

TSE. 1983. TS 4085: Wood - determination of volumetric shrinkage. TSE: Ankara, Turkey (in Turkish).

TSE, 1983. TS 4086: Wood - determination of volumetric swelling. TSE: Ankara, Turkey (in Turkish).

TSE. 1984. TS 4176: Wood - sampling sample trees and long for determination of physical and mechanical properties of wood in homogeneous stands. TSE: Ankara, Turkey (in Turkish).

Usta, M. 1993. Comparing wood and bark constituents of endemic species. In Proceedings Second Forest Products Symposium, September 6-9. Karadeniz Technical University, Faculty of Forestry, ORENKO 93, Trabzon, Turkey, pp: 288-292. (in Turkish).

Wise, L.E.; Karl, H.L. 1962. Cellulose and hemicellulose in pulp and paper science and technology. McGraw Hill Book Co: New York.

Yaltırık, F.; Efe, A. 1994. Dendroloji ders kitab1, gymnospermae-angiospermae. İstanbul Üniversitesi Yayınları: İstanbul, Türkiye (in Turkish).

Yeh, T.F.; Braun, J.L.; Goldfarb, B.; Chang, H.M.; Kadla, J.F.; 2006. Morphological and chemical variations between juvenile wood, mature wood, and compression wood of loblolly pine (Pinus taeda L.). Holzforschung 60(1): 1-8. https://doi.org/10.1515/HF.2006.001 